\title{
Front Matter: Volume 6828
}

, "Front Matter: Volume 6828," Proc. SPIE 6928, Active and Passive Smart Structures and Integrated Systems 2008, 692801 (2 May 2008); doi: 10.1117/12.797945

EDIE $\quad$ Event: SPIE Smart Structures and Materials + Nondestructive Evaluation and SPIE. Health Monitoring, 2008, San Diego, California, United States 


\title{
PROCEEDINGS OF SPIE
}

\section{Active and Passive Smart Structures and Integrated Systems 2008}

\author{
Mehdi Ahmadian \\ Editor \\ 10-13 March 2008 \\ San Diego, California, USA \\ Sponsored by \\ SPIE \\ Cosponsored by \\ American Society of Mechanical Engineers (USA) \\ Cooperating Organizations \\ Intelligent Materials Forum (Japan) \\ Jet Propulsion Laboratory (USA) \\ National Science Foundation (USA) \\ Published by \\ SPIE
}

Volume 6928 
The papers included in this volume were part of the technical conference cited on the cover and title page. Papers were selected and subject to review by the editors and conference program committee. Some conference presentations may not be available for publication. The papers published in these proceedings reflect the work and thoughts of the authors and are published herein as submitted. The publisher is not responsible for the validity of the information or for any outcomes resulting from reliance thereon.

Please use the following format to cite material from this book:

Author(s), "Title of Paper," in Active and Passive Smart Structures and Integrated Systems 2008, edited by Mehdi Ahmadian, Proceedings of SPIE Vol. 6928 (SPIE, Bellingham, WA, 2008) Article CID Number.

ISSN 0277-786X

ISBN 9780819471147

Published by

SPIE

P.O. Box 10, Bellingham, Washington 98227-0010 USA

Telephone +1 3606763290 (Pacific Time) · Fax +1 3606471445

SPIE.org

Copyright (C 2008, Society of Photo-Optical Instrumentation Engineers

Copying of material in this book for internal or personal use, or for the internal or personal use of specific clients, beyond the fair use provisions granted by the U.S. Copyright Law is authorized by SPIE subject to payment of copying fees. The Transactional Reporting Service base fee for this volume is $\$ 18.00$ per article (or portion thereof), which should be paid directly to the Copyright Clearance Center (CCC), 222 Rosewood Drive, Danvers, MA 01923. Payment may also be made electronically through CCC Online at copyright.com. Other copying for republication, resale, advertising or promotion, or any form of systematic or multiple reproduction of any material in this book is prohibited except with permission in writing from the publisher. The CCC fee code is $0277-786 \mathrm{X} / 08 / \$ 18.00$.

Printed in the United States of America.

Publication of record for individual papers is online in the SPIE Digital Library.

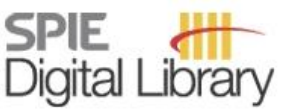

SPIEDigitallibrary.org

Paper Numbering: Proceedings of SPIE follow an e-First publication model, with papers published first online and then in print and on CD-ROM. Papers are published as they are submitted and meet publication criteria. A unique, consistent, permanent citation identifier (CID) number is assigned to each article at the time of the first publication. Utilization of CIDs allows articles to be fully citable as soon they are published online, and connects the same identifier to all online, print, and electronic versions of the publication. SPIE uses a six-digit CID article numbering system in which:

- The first four digits correspond to the SPIE volume number.

- The last two digits indicate publication order within the volume using a Base 36 numbering system employing both numerals and letters. These two-number sets start with 00, 01, 02, 03, 04, 05, $06,07,08,09,0 A, 0 B \ldots 0 Z$, followed by $10-12,20-2 Z$, etc.

The CID number appears on each page of the manuscript. The complete citation is used on the first page, and an abbreviated version on subsequent pages. Numbers in the index correspond to the last two digits of the six-digit CID number. 


\section{Contents}

$\begin{aligned} \text { xi } & \text { Symposium Committee } \\ \text { xiii } & \text { Conference Committee }\end{aligned}$

SESSION 1 ENERGY HARVESTING AND SCAVENGING I

692802 Mission performance of a solar- and microwave-powered aircraft [6928-01]

A. Wickenheiser, E. Garcia, Cornell Univ. (USA)

692805 Stiffness nonlinearity as a means for resonance frequency tuning and enhancing mechanical robustness of vibration power harvesters [6928-04]

J. Loverich, R. Geiger, J. Frank, KCF Technologies, Inc. (USA)

692806 Micro-solenoid electromagnetic power harvesting for vibrating systems [6928-05]

T. Reissman, J. S. Park, E. Garcia, Cornell Univ. (USA)

692807 Vibration energy harvesters with non-linear compliance [6928-06]

S. G. Burrow, L. R. Clare, A. Carrella, D. Barton, Univ. of Bristol (United Kingdom)

\section{SESSION 2 ENERGY HARVESTING AND SCAVENGING II}

692808 Ambient energy harvesting using ferroelectric materials [6928-07]

D. Guyomar, G. Sebald, S. Pruvost, M. Lallart, Institut National des Sciences Appliquées de Lyon (France)

692809 Energy management of multi-component power harvesting systems [6928-09]

R. B. MacCurdy, T. Reissman, E. Garcia, Cornell Univ. (USA)

6928 OA Power conditioning for energy harvesting [6928-10]

L. R. Clare, S. G. Burrow, Univ. of Bristol (United Kingdom)

$6928 \mathrm{OB}$ Effect of bias conditions on the optimal energy harvesting using magnetostrictive materials [6928-11]

T. Sevaciuc-Osório, M. F. Daqaq, Clemson Univ. (USA)

\section{SESSION 3 ENERGY HARVESTING AND SCAVENGING III}

6928 OC Performance comparison of implantable piezoelectric energy harvesters [6928-13]

C. Mo, Univ. of Pittsburgh (USA); L. J. Radziemski, Piezo Energy Technologies, LLC (USA);

W. W. Clark, Univ. of Pittsburgh (USA)

6928 OE An investigation into active piezoelectric nanocomposites for distributed energy harvesting [6928-72]

Y. Liu, H. A. Sodano, Arizona State Univ. (USA) 
$6928 \mathrm{Ol} \quad$ Piezoelectric energy harvesting from an L-shaped beam-mass structure [6928-19]

A. Erturk, J. M. Renno, D. J. Inman, Virginia Polytechnic Institute and State Univ. (USA)

SESSION 4 ADVANCED MATERIALS AND STRUCTURES

6928 0J Vibroacoustics and wave propagation of novel chiral honeycombs [6928-20]

K. F. Tee, Univ. of Bristol (United Kingdom); A. Spadoni, Georgia Institute of Technology (USA); F. Scarpa, Univ. of Bristol (United Kingdom); M. Ruzzene, Georgia Institute of Technology (USA)

6928 OK Characterization of porous substrates for biochemical energy conversion devices [6928-21]

V. B. Sundaresan, S. A. Sarles, D. J. Leo, Virginia Polytechnic Institute and State Univ. (USA)

$69280 \mathrm{M}$ A variable transverse stiffness sandwich structure using fluidic flexible matrix composites (F² MC) [6928-84]

S. Li, A. Lotfi, Y. Shan, K. W. Wang, C. D. Rahn, C. E. Bakis, The Pennsylvania State Univ. (USA)

\section{SESSION $5 \quad$ AUTOMOTIVE AND TRANSPORTATION SYSTEMS}

6928 ON Development of adaptive helicopter seat systems for aircrew vibration mitigation [6928-23]

Y. Chen, V. Wickramasinghe, D. G. Zimcik, National Research Council Canada (Canada)

6928 OP Application of orthogonal eigenstructure control to flight control design [6928-25] M. A. Rastgaar, M. Ahmadian, S. C. Southward, Virginia Polytechnic Institute and State Univ. (USA)

$69280 Q \quad$ Geometric optimization of controllable magnetorheological shock absorber for commercial passenger vehicle [6928-26]

K.-G. Sung, Y.-M. Han, S.-B. Choi, Inha Univ. (South Korea)

6928 OR Power harvesting for railroad track health monitoring using piezoelectric and inductive devices [6928-27]

C. A. Nelson, S. R. Platt, D. Albrecht, V. Kamarajugadda, Univ. of Nebraska, Lincoln (USA); M. Fateh, Federal Railroad Administration (USA)

\section{SESSION 6 SMAS INTEGRATED SYSTEMS I}

6928 OT Multifunctional SMA-based smart inhaler system for improved aerosol drug delivery: design and fabrication [6928-29]

M. E. Pausley, S. Seelecke, North Carolina State Univ. (USA)

6928 OU Dynamics and control of buckling type devices using SMA wire integrated beam [6928-30] V. Jha, K. Dasharathi, D. Roy Mahapatra, Indian Institute of Science, Bangalore (India) 
6928 OW Experimental investigation and numerical evaluation of an innovative shape memory alloy damper [6928-34]

W. Ren, Hebei Univ. of Technology (China) and Dalian Univ. of Technology (China); H. Li, Dalian Univ. of Technology (China); G. Song, Univ. of Houston (USA)

$69280 X \quad$ Characterization of $\mathrm{Ni}_{19.5} \mathrm{Ti}_{50.5} \mathrm{Pd}_{25} \mathrm{Pt}_{5}$ high-temperature shape memory alloy springs and their potential applications in aeronautics [6928-35]

A. Stebner, S. A. Padula II, R. D. Noebe, NASA Glenn Research Ctr. (USA); D. D. Quinn, The Univ. of Akron (USA)

6928 OY Testing of SMA-enabled active chevron prototypes under representative flow conditions [6928-36]

T. L. Turner, R. H. Cabell, R. J. Cano, R. J. Silcox, NASA Langley Research Ctr. (USA)

\section{SESSION 8 SMART MATERIALS AND STRUCTURES OPTIMIZATION}

692810 Optimization and implementation of the smart joint actuator [6928-38]

J. Manzo, E. Garcia, Cornell Univ. (USA)

692811 Topology optimization of a plate coupled with acoustic cavity [6928-39]

W. Akl, A. El-Sabbagh, Ain Shams Univ. (Egypt); K. Al-Mitani, A. Baz, Univ. of Maryland, College Park (USA)

692812 Turbomachinery blades damping thanks to optimized shunted piezoelectric circuits [6928-40]

S. Livet, Snecma (France); M. Collet, M. Berthillier, Femto-ST Institute, Univ. de FrancheComté (France); P. Jean, Snecma (France); J. M. Cote, Femto-ST Institute, Univ. de Franche-Comté (France)

\section{SESSION 9 MODELING, SIMULATION, AND DESIGN OF CONTROLLED SYSTEMS I}

692813 Active optimal control of SSI system based on the finite element model of SSI system and shaking table test study [6928-41]

F. X. Wang, Harbin Institute of Technology (China) and Heilongjiang Science and Technology Institute (China); J. P. Ou, Harbin Institute of Technology (China) and Dalian Univ. of Technology (China)

692814 Applicability of AMD controller based on the fixed-base structure to control SSI system [6928-42]

F. X. Wang, Heilongjiang Science and Technology Institute (China) and Harbin Institute of Technology (China); J. P. Ou, Harbin Institute of Technology (China) and Dalian Univ. of Technology (China)

692816 Piezo shunt power flow optimization for composite beam stabilization [6928-44] M. Collet, Femto-ST Institute, Univ. de Franche-Comté (France); K. A. Cunefare, B. Beck, Georgia Institute of Technology (USA) 
692817 Two-step recursive method for dynamic response computation based on principle of minimum transformed energy [6928-45]

D. Li, Beijing Jiaotong Univ. (China); T. Liu, D. Li, Shenyang Jianzhu Univ. (China)

\section{SESSION 10 SMART MATERIALS AND STRUCTURES OPTIMIZATION II}

692819 Sensitivity enhancement for damage detection in linear systems using optimal feedback auxiliary signals and system augmentation [6928-47]

K. D'Souza, B. I. Epureanu, Univ. of Michigan (USA)

69281 A Sensitivity based performance evaluation and reliability assessment of adaptive systems [6928-49]

K. Wolf, S.-O. Han, H. Hanselka, Technische Univ. Darmstadt (Germany)

\section{SESSION 11 MR FLUIDS INTEGRATED SYSTEMS}

6928 1B Temperature sensitive stability of feedback controllers for MR dampers [6928-50]

D. C. Batterbee, N. D. Sims, The Univ. of Sheffield (United Kingdom)

6928 1C Design and modeling of a mixed mode magnetorheological (MR) fluid mount [6928-51]

C. Ciocanel, Northern Arizona Univ. (USA); T. Nguyen, M. Elahinia, Univ. of Toledo (USA)

6928 ID A new magnetorheological fluid-elastomer vibration isolator [6928-52]

D. York, X. Wang, F. Gordaninejad, Univ. of Nevada, Reno (USA)

6928 IE Semi-active control of torsionally responsive structures [6928-53]

D. A. Shook, Skidmore, Owings, and Merrill (USA); P. N. Roschke, Texas A\&M Univ. (USA);

P.-Y. Lin, National Ctr. for Research on Earthquake Engineering (Taiwan); C.-H. Loh, National Taiwan Univ. (Taiwan)

6928 IG Development and testing of a magnetorheological actuator for an assistive knee brace [6928-91]

J. Chen, W.-H. Liao, The Chinese Univ. of Hong Kong (Hong Kong China)

\section{SESSION 12 BIOLOGY INSPIRED SYSTEMS}

$6928 \mathrm{1H} \quad$ Application of macro fibre composite in driving a tail of a biomimetic fish [6928-55]

D. Wang, W. Yin, Y. Liu, J. Leng, Harbin Institute of Technology (China)

$692811 \quad$ Insect-inspired wing actuation structures based on ring-type resonators [6928-56] C. T. Bolsman, J. F. L. Goosen, F. van Keulen, Delft Univ. of Technology (Netherlands)

$69281 \mathrm{~J} \quad$ Passive self repairing and active self sensing in multifunctional polymer composites [6928-59]

C. Dry, Natural Process Design, Inc. (USA) 
6928 1K Seismic retrofitting of bridge columns using shape memory alloys [6928-60]

B. Andrawes, M. Shin, Univ. of Illinois at Urbana-Champaign (USA)

\section{SESSION $14 \quad$ INTEGRATED SYSTEMS IN BIONICS AND NATURE-INSPIRED TECHNOLOGIES}

$69281 \mathrm{M} \quad$ Bio-inspired shape memory alloy actuated hexapod robot [6928-68]

M. Berry, E. Garcia, Cornell Univ. (USA)

6928 iN Flapping performance and simulation of an insect-mimicking flapper actuated by a compressed unimorph piezoelectric composite actuator [6928-64]

Q. V. Nguyen, H. C. Park, N. S. Goo, D. Byun, Konkuk Univ. (South Korea)

692810 An aeroelastic analysis of a flexible flapping wing using modified strip theory [6928-65]

D.-K. Kim, Korea Aerospace Research Institute (South Korea); J.-S. Lee, J.-Y. Lee, J.-H. Han, Korea Advanced Institute of Science and Technology (South Korea)

6928 IP Numerical analyses of stabilization and control for flapping-wing flight [6928-66] J.-Y. Lee, Korea Advanced Institute of Science and Technology (South Korea); D.-K. Kim, Korea Aerospace Research Institute (South Korea); J.-S. Lee, J.-H. Han, Korea Advanced Institute of Science and Technology (South Korea)

\section{SESSION 15 INTEGRATION OF ACTIVE/PASSIVE MATERIALS AND DEVICES INTO INTEGRATED SYSTEMS I}

$69281 Q \quad$ Membrane reflectors with variable area electrostatic actuation for laser beam guidance [6928-69]

M. A. Wickersham, A. W. Downs, N. Kingsbury, U. A. Korde, South Dakota School of Mines and Technology (USA)

6928 IR Integration, control, and applications of multifunctional linear actuators [6928-70]

K. Ma, M. N. Ghasemi-Nejhad, Univ. of Hawaii at Manoa (USA)

6928 is Robust vibration suppression of an adaptive circular composite plate for satellite thrust vector control [6928-71]

S. Yan, K. Ma, M. N. Ghasemi-Nejhad, Univ. of Hawaii at Manoa (USA)

\section{SESSION 16 INTEGRATION OF ACTIVE/PASSIVE MATERIALS AND DEVICES INTO INTEGRATED SYSTEMS II}

6928 1T Rectifier-less piezoelectric micro power generator [6928-73]

A. Hajati, S.-G. Kim, Massachusetts Institute of Technology (USA)

$69281 \mathrm{U}$ Performance characteristics of a high frequency jetting dispenser featuring piezoelectric actuator [6928-74]

Q.-H. Nguyen, B.-Y. Yun, S.-B. Choi, Inha Univ. (South Korea)

6928 1V A blended polymer electret-based micro-electronic power generator [6928-75]

W.-C. Ko, B.-S. Lee, J.-L. Chen, S.-C. Lin, W.-J. Wu, National Taiwan Univ. (Taiwan); C.-K. Lee, National Taiwan Univ. (Taiwan) and Industrial Technology Research Institute (Taiwan) 
6928 IW Piezo-electric control of nonlinear modal interaction in stiffened structures [6928-76]

S. Sridharan, S. Kim, Washington Univ. in St. Louis (USA)

SESSION 17 ACTIVE/SEMI-ACTIVE/PASSIVE VIBRATION CONTROL

$69281 \mathrm{X}$ Experimental assessment of negative impedance shunts for vibration suppression on a beam [6928-78]

B. S. Beck, K. A. Cunefare, Georgia Institute of Technology (USA); M. Collet, Femto-ST Institute, Univ. de Franche-Comté (France)

$69281 \mathrm{Z}$ Several topics from active vibration control technique using piezoelectric films [6928-80] T. Nishigaki, Kinki Univ. (Japan)

692820 Active damping control of micromachined devices in a low atmospheric pressure environment [6928-81]

S. J. Kim, C. Chen, G. Flowers, R. Dean, Auburn Univ. (USA)

$692821 \quad$ Frequency response analysis of vibration system with parametric excitation of damping coefficient [6928-82]

D. Iba, A. Masuda, A. Sone, Kyoto Institute of Technology (Japan)

692822 Recent studies of electronic tuning of out of plane stiffness and dissipation of piezoelectric polymer membranes [6928-83]

M. A. Wickersham, T. J. Zelfer, U. A. Korde, E. A. Petersen, South Dakota School of Mines and Technology (USA)

\section{SESSION 18 AIRCRAFT AND MAV/UAV SYSTEMS}

692823 Investigation of an energy harvesting small unmanned air vehicle [6928-85]

K. C. Magoteaux, Univ. of Dayton (USA); B. Sanders, Air Force Research Lab. (USA);

H. A. Sodano, Arizona State Univ. (USA)

692824 Vibration energy harvesting for unmanned aerial vehicles [6928-86]

S. R. Anton, D. J. Inman, Virginia Polytechnic Institute and State Univ. (USA)

692825 Analysis of bat wings for morphing [6928-87]

E. A. Leylek, J. E. Manzo, E. Garcia, Cornell Univ. (USA)

SESSION 19 MODELING, ANALYSIS, AND DESIGN OF STRUCTURAL SENSING AND ACTUATION IN INTEGRATED SYSTEMS

692826 Behavior of thin lightweight structures under propagating waves [6928-89]

E. A. Petersen, Univ. of Nebraska, Lincoln (USA); K. A. Barnes, U. A. Korde, South Dakota School of Mines and Technology (USA)

692828 Design of dual-stage actuation system for high precision optical manufacturing [6928-92] W. Dong, J. Tang, Univ. of Connecticut (USA); Y. EIDeeb, Gerber Scientific International Inc. (USA) 
$692829 \quad$ Bistable mechanisms for morphing rotors [6928-94]

T. Johnson, F. Gandhi, M. Frecker, Pennsylvania State Univ. (USA)

6928 2A Shape control of a morphing structure (rotor blade) using a shape memory alloy actuator system [6928-95]

G. S. Bushnell, D. Arbogast, R. Ruggeri, Boeing Phantom Works (USA)

6928 2B Prediction of aircraft dynamics with shape changing wings [6928-96]

E. Cuji, E. Garcia, Cornell Univ. (USA)

SESSION 21 FLEXIBLE ROBOTIC SYSTEMS

6928 2C Vibration suppression of a flexible manipulator using self-tuning optimal control and LIPCA [6928-98]

V. P. Phan, N. S. Goo, H. C. Park, Konkuk Univ. (South Korea)

6928 2D Numerical analysis of deformation of a beam with thin piezoelectric actuators partially debonded and buckling [6928-99]

T. Ikeda, Nagoya Univ. (Japan); R. Samikkannu, National Aerospace Labs. (India); T. Ueda, Nagoya Univ. (Japan)

\section{POSTER SESSION}

6928 2F BATMAV: a biologically inspired micro-air vehicle for flapping flight: kinematic modeling [6928-58]

G. Bunget, S. Seelecke, North Carolina State Univ. (USA)

$69282 G \quad$ Analysis of the dynamics of the vibratory tabular valve [6928-102]

K. Ragulskis, Kaunas Univ. of Technology (Lithuania); V. Naginevicius, Kaunas Univ. of Technology (Lithuania) and Kaunas Technical College (Lithuania); A. Palevicius, Kaunas Univ. of Technology (Lithuania); R. Palevicius, Kaunas Univ. of Technology (Lithuania) and Kaunas Technical College (Lithuania)

$69282 \mathrm{H} \quad$ Analysis dynamics of piezoelectric optical scanner with periodical microstructure [6928-103]

A. Palevicius, G. Janusas, V. Ostasevicius, R. Bansevicius, Kaunas Univ. of Technology (Lithuania); A. Busilas, Kaunas Univ. of Technology (Lithuania) and Vilnius Gediminas Technical Univ. (Lithuania); D. Rubliauskas, Kaunas Univ. of Technology (Lithuania)

$692821 \quad$ Limit of feedback gains of collocated sensor and actuator pairs for beams [6928-104] Y.-S. Lee, Univ. of Incheon (South Korea); S.-K. Lee, Inha Univ. (South Korea)

6928 2J A new optimal vibration control system for two connection structures [6928-105] J. L. Zhang, Northwestern Polytechnical Univ. (China) and Xiamen Univ. (China); A. Q. Yang, Y. Song, Xiamen Univ. (China); J. S. Jiang, Northwestern Polytechnical Univ. (China) 
6928 2K Flexible multisensors for robotics [6928-106]

M. Santoro, ENEA Research Ctr. Casaccia (Italy)

$69282 \mathrm{M}$ Experimental evaluation of a flapping-wing aerodynamic model for MAV applications [6928-108]

J.-S. Lee, Korea Advanced Institute of Science and Technology (South Korea); D.-K. Kim, Korea Aerospace Research Institute (South Korea); J.-Y. Lee, J.-H. Han, Korea Advanced Institute of Science and Technology (South Korea)

$69282 \mathrm{~N} \quad$ Experimental and analytical investigation on innovative hybrid shape memory alloys dampers for structural control [6928-109]

H. Li, H. Qian, Dalian Univ. of Technology (China); G. Song, Univ. of Houston (USA)

692820 Self-optimising piezoelectric damping [6928-110]

M. Greaves, Cranfield Univ. (United Kingdom); A. Bowles, R. McBride, T. Jarman, J. Gore, QinetiQ Ltd. (United Kingdom)

6928 2P Design and characterisation of micro-diaphragm for low power drug delivery applications [6928-112]

D. W. Dissanayake, S. F. Al-Sarawi, T.-F. Lu, D. Abbott, Univ. of Adelaide (Australia)

$69282 \mathrm{Q}$ Passive and active data porting to composite integrated optical fibers via integrated optics [6928-113]

M. E. Teitelbaum, Univ. of Delaware (USA); D. J. O'Brien, E. D. Wetzel, Army Research Lab. (USA); K. W. Goossen, Univ. of Delaware (USA)

Author Index 


\title{
Symposium Committee
}

\author{
Symposium Chairs
}

Alison B. Flatau, University of Maryland, College Park (USA)

George Y. Baaklini, NASA Glenn Research Center (USA)

Donald J. Leo, Virginia Polytechnic Institute and State University (USA)

Kara J. Peters, North Carolina State University (USA)

Executive Committee

Alison B. Flatau, University of Maryland, College Park (USA)

George Y. Baaklini, NASA Glenn Research Center (USA)

Donald J. Leo, Virginia Polytechnic Institute and State University (USA)

Kara J. Peters, North Carolina State University (USA)

Mehdi Ahmadian, Virginia Polytechnic Institute and State University (USA)

Yoseph Bar-Cohen, Jet Propulsion Laboratory (USA)

Emilio P. Calius, Industrial Research Ltd. (New Zealand)

Marcelo J. Dapino, The Ohio State University (USA)

L. Porter Davis, Honeywell, Inc. (USA)

Michael A. Demetriou, Worcester Polytechnic Institute (USA)

Aaron A. Diaz, Pacific Northwest National Laboratory (USA)

Wolfgang Ecke, IPHT Jena (Germany)

Mehrdad N. Ghasemi-Nejhad, University of Hawai'i at Manoa (USA)

Victor Giurgiutiu, University of South Carolina (USA)

B. Kyle Henderson, Air Force Research Laboratory (USA)

Kumar V. Jata, Air Force Research Laboratory (USA)

Tribikram Kundu, The University of Arizona (USA)

Douglas K. Lindner, Virginia Polytechnic Institute and State University (USA)

Ajit K. Mal, University of California, Los Angeles (USA)

M. Brett McMickell, Honeywell, Inc. (USA)

Norbert G. Meyendorf, Fraunhofer-Institut für Zerstörungsfreie

Prüfverfahren (Germany) and University of Dayton (USA)

Zoubeida Ounaies, Texas A\&M University (USA)

Andrei M. Shkel, University of California, Irvine (USA)

Peter J. Shull, The Pennsylvania State University (USA)

Masayoshi Tomizuka, University of California, Berkeley (USA)

Vijay K. Varadan, University of Arkansas (USA)

Dietmar W. Vogel, Fraunhofer-Institut für Zuverlässigkeit und Mikrointegration (Germany)

H. Felix Wu, National Institute of Standards and Technology (USA)

Chung-Bang Yun, Korea Advanced Institute of Science and Technology

(South Korea) 
Downloaded From: https://www.spiedigitallibrary.org/conference-proceedings-of-spie on 26 Apr 2023

Terms of Use: https://www.spiedigitallibrary.org/terms-of-use 


\title{
Conference Committee
}

\author{
Conference Chair
}

Mehdi Ahmadian, Virginia Polyłechnic Institute and State University (USA)

\section{Conference Cochairs}

Mehrdad N. Ghasemi-Nejhad, University of Hawai'i at Manoa (USA)

Donald J. Leo, Virginia Polytechnic Institute and State University (USA)

Program Committee

Gregory S. Agnes, Jet Propulsion Laboratory (USA)

Eric H. Anderson, CSA Engineering, Inc. (USA)

Hiroshi Asanuma, Chiba University (Japan)

Amr M. Baz, University of Maryland, College Park (USA)

Diann E. Brei, University of Michigan (USA)

Gregory P. Carman, University of California, Los Angeles (USA)

Aditi Chattopadhyay, Arizona State University (USA)

Seung-Bok Choi, Inha University (South Korea)

William W. Clark, University of Pittsburgh (USA)

Mohammad H. Elahinia, University of Toledo (USA)

Alison B. Flatau, University of Maryland, College Park (USA)

Farhan Gandhi, The Pennsylvania State University (USA)

Ephrahim Garcia, Cornell University (USA)

Victor Giurgiutiu, University of South Carolina (USA)

Fernando D. Goncalves, Lord Corporation (USA)

Faramarz Gordaninejad, University of Nevada, Reno (USA)

Nakhiah C. S. Goulbourne, Virginia Polytechnic Institute and State University (USA)

Tristram T. Hyde, NASA Goddard Space Flight Center (USA)

Daniel J. Inman, Virginia Polytechnic Institute and State University (USA)

Conor D. Johnson, CSA Engineering, Inc. (USA)

Seung Jo Kim, Seoul National University of Technology (South Korea) Jeong-Hoi Koo, Miami University (USA)

George Andre Lesieutre, The Pennsylvania State University (USA)

Wei-Hsin Liao, The Chinese University of Hong Kong (Hong Kong

China)

Arnold Lumsdaine, The University of Tennessee (USA)

John A. Main, Defense Advanced Research Projects Agency (USA)

Yuji Matsuzaki, Nagoya University (Japan)

Samir A. Nayfeh, Massachusetts Institute of Technology (USA) 
Roger Ohayon, Conservatoire National des Arts et Métiers (France)

Mohammad Rastgaar Aagaah, Virginia Polytechnic Institute and State University (USA)

Dale Ruebsamen, Honeywell, Inc. (USA)

Steve C. Southward, Virginia Polytechnic Institute and State University (USA)

Roger Stanway, The University of Sheffield (United Kingdom)

Friedrich K. Straub, The Boeing Company (USA)

Jian Qiao Sun, University of Delaware (USA)

Nader Vahdati, Nanyang Technological University (Singapore)

Kon-Well Wang, The Pennsylvania State University (USA)

Norman M. Wereley, University of Maryland, College Park (USA)

\section{Session Chairs}

1 Energy Harvesting and Scavenging I

Henry A. Sodano, Arizona State University (USA)

Gyuhae Park, Los Alamos National Laboratory (USA)

2 Energy Harvesting and Scavenging II

Donald J. Leo, Virginia Polytechnic Institute and State University (USA)

Henry A. Sodano, Arizona State University (USA)

3 Energy Harvesting and Scavenging III

Nakhiah C. S. Goulbourne, Virginia Polytechnic Institute and State University (USA)

Gyuhae Park, Los Alamos National Laboratory (USA)

$4 \quad$ Advanced Materials and Structures

William W. Clark, University of Pittsburgh (USA)

Kon-Well Wang, The Pennsylvania State University (USA)

$5 \quad$ Automotive and Transportation Systems

Mehdi Ahmadian, Virginia Polytechnic Institute and State University (USA)

6 SMAs Integrated Systems I

Mehdi Ahmadian, Virginia Polytechnic Institute and State University (USA)

Mehrdad N. Ghasemi-Nejhad, University of Hawaili at Manoa (USA)

7 SMAs Integrated Systems II

Gregory P. Carman, University of California, Los Angeles (USA)

Steve C. Southward, Virginia Polytechnic Institute and State University (USA) 
9 Modeling, Simulation, and Design of Controlled Systems I

Mehrdad N. Ghasemi-Nejhad, University of Hawai'i at Manoa (USA)

10 Smart Materials and Structures Optimization II

Daniel J. Inman, Virginia Polytechnic Institute and State University (USA)

Mohammad Rastgaar Aagaah, Virginia Polytechnic Institute and State University (USA)

11 MR Fluids Integrated Systems

Norman M. Wereley, University of Maryland, College Park (USA)

Mehdi Ahmadian, Virginia Polytechnic Institute and State University (USA)

12 Biology Inspired Systems

Ephrahim Garcia, Cornell University (USA)

Donald J. Leo, Virginia Polytechnic Institute and State University (USA)

13 Civil Systems

Seung-Bok Choi, Inha University (South Korea)

Aditi Chattopadhyay, Arizona State University (USA)

14 Integrated Systems in Bionics and Nature-Inspired Technologies

Yuji Matsuzaki, Nagoya University (Japan)

Ephrahim Garcia, Cornell University (USA)

15 Integration of Active/Passive Materials and Devices into Integrated Systems I

Mehrdad N. Ghasemi-Nejhad, University of Hawai'i at Manoa (USA)

Eric H. Anderson, CSA Engineering, Inc. (USA)

16 Integration of Active/Passive Materials and Devices into Integrated Systems II

Mehrdad N. Ghasemi-Nejhad, University of Hawaili at Manoa (USA)

Mohammad Rastgaar Aagaah, Virginia Polytechnic Institute and State University (USA)

17 Active/Semi-Active/Passive Vibration Control

Joseph R. Maly, CSA Engineering, Inc. (USA)

Nakhiah C. S. Goulbourne, Virginia Polytechnic Institute and State University (USA) 
Aircraft and MAV/UAV Systems

Pablo Bandera, Honeywell, Inc. (USA)

Donald J. Leo, Virginia Polytechnic Institute and State University (USA)

19 Modeling, Analysis, and Design of Structural Sensing and Actuation in Integrated Systems

Nakhiah C. S. Goulbourne, Virginia Polytechnic Institute and State University (USA)

Mohammad Rastgaar Aagaah, Virginia Polytechnic Institute and State University (USA)

20 Morphing Structures and Aircrafts

Nakhiah C. S. Goulbourne, Virginia Polytechnic Institute and State University (USA)

Mehdi Ahmadian, Virginia Polytechnic Institute and State University (USA)

$21 \quad$ Flexible Robotic Systems

Mohammad Rastgaar Aagaah, Virginia Polytechnic Institute and State University (USA) 